\title{
Ginseng for managing menopause symptoms: a systematic review of randomized clinical trials
}

\author{
Myung-Sunny Kim ${ }^{1 \dagger}$, Hyun-Ja Lim ${ }^{2 \dagger}$, Hye Jeong Yang ${ }^{1}$, Myeong Soo Lee ${ }^{3 *}$, Byung-Cheul Shin ${ }^{4}$, and \\ Edzard Ernst ${ }^{5}$
}

${ }^{1}$ Korea Food Research Institute, Seongnam 463-746, Korea

${ }^{2}$ Department of Nursing, Chodang University, Muan 534-701, Korea

${ }^{3}$ Medical Research Division, Korea Institute of Oriental Medicine, Daejeon 305-811, Korea

${ }^{4}$ Division of Clinical Medicine, School of Korean Medicine, Pusan National University, Yangsan 626-870, Korea

${ }^{5}$ Complementary Medicine, Peninsula Medical School, University of Exeter, Exeter EX2 4SG, UK

The aim of this review was to assess the effectiveness of ginseng as a treatment option for managing menopause symptoms. We searched the literature using 11 databases from their inception to 26 September 2012 and included all randomised clinical trials (RCTs) that compared any type of ginseng to a placebo controls in postmenopausal women. The methodological quality of all studies was assessed using a Cochrane risk of bias tool. Four RCTs met our inclusion criteria. Most RCTs had high risk of bias. One RCT showed that Korean red ginseng (KRG) significantly improved sexual arousal and global health compared with placebo. Another RCT reported the superiority of KRG over placebo for treating menopause symptoms on Kupperman's index and menopausal rating score. The third RCT failed to show a significant effect of KRG on hot flash frequency compared to placebo. The fourth RCT found beneficial effects of ginseng compared to placebo on depression and well-being. In conclusion, the evidence on ginseng as an effective treatment for managing menopause symptoms is limited. Most of the RCTs are burdened with a high risk of bias. Thus firm conclusions cannot be drawn. Rigorous studies seem warranted.

Keywords: Panax ginseng, Complementary medicine, Menopause symptoms, systematic review, randomised clinical trial

\section{INTRODUCTION}

Menopause is often accompanied by a range of symptoms including mood changes, hot flashes, sleeplessness, vaginal dryness, decreased libido, and impairment of cognitive function [1,2]. Some of these symptoms can be effectively treated with hormone replacement therapy (HRT). However, possible adverse effects of long-term HRT have contributed to a high prevalence of use of complementary therapies by menopausal women. Some of the most popular of these treatments include herbal

(cc) This is an Open Access article distributed under the terms of the Creative Commons Attribution Non-Commercial License (http://creativecommons.org/licenses/by-nc/3.0/) which permits unrestricted non-commercial use, distribution, and reproduction in any medium, provided the original work is properly cited. supplements [2,3].

Ginseng is one of the most popular medicinal herb [4-6]. It has been reported to be effective in preventing certain cancers, improving erectile dysfunction, and preventing the common cold $[4,7,8]$. The value of ginseng for improving menopause symptoms is limited and contradictory. Currently, except for one traditional review [9], no systematic review of this subject is available.

The objective of this systematic review was to sum-

Received 15 Jul. 2012, Revised 27 Sep. 2012, Accepted 27 Sep. 2012

${ }^{\dagger}$ These authors contributed equally to this work.

*Corresponding author

E-mail: drmslee@gmail.com

Tel: +82-42-868-9266, Fax: +82-42-868-9299 
marize and critically assess the evidence from placebocontrolled randomized clinical trials (RCTs) of ginseng in managing the symptoms of postmenopausal women.

\section{MATERIALS AND METHODS}

\section{Data sources}

The following databases were searched from their inception through 26 September 2012: MEDLINE, AMED, CINAHL, EMBASE, 5 Korean medical databases (Korean Studies Information, DBPIA, Korea Institute of Science and Technology Information, KoreaMed, and the Research Information Service System), Chinese medical database (China Academic Journal), and The Cochrane Library 2012, issue 9. The search strategies used were shown in Appendix 1. The search strategy was used with modification of this for each database. In addition, our own files and relevant journal (Focus on Alternative and Complementary Therapies) were manually searched. Hard copies of all articles were obtained and read in full.

\section{Study selection}

All prospective randomized clinical studies that compared the effects of any type of ginseng on menopause symptoms with a placebo were included. Trials in which ginseng formed part of a complex herbal medicine were excluded. No language restrictions were imposed. Dissertations and abstracts were also included.

\section{Data extraction, quality, and validity assessment}

All articles were read by three independent reviewers (MSK, HJL, and MSL) who extracted data from the articles according to predefined criteria (Table 1). Risk of bias of Cochrane collaborations was used for the assessment of the included studies' quality in six domains: sequence generation, allocation concealment, blinding, incomplete outcome data, selective outcome reporting, and other sources of bias [10]. Two authors assessed the quality of the included studies independently and dis-

Table 1. Summary of randomized clinical trials of ginseng for menopause symptoms compared with placebo control

\begin{tabular}{|c|c|c|c|c|c|c|c|c|c|c|}
\hline $\begin{array}{c}\text { First } \\
\text { author } \\
\text { (yr) [ref] }\end{array}$ & Design & $\begin{array}{l}\text { Sample size } \\
\text { conditions }\end{array}$ & $\begin{array}{l}\text { Age } \\
\text { range } \\
(\mathrm{yr})\end{array}$ & $\begin{array}{l}\text { Interven- } \\
\text { tion }\end{array}$ & $\begin{array}{c}\text { Dose } \\
(\mathrm{mg} / \mathrm{d})\end{array}$ & $\begin{array}{l}\text { Treatment } \\
\text { duration } \\
\text { (wk) }\end{array}$ & $\begin{array}{l}\text { Main outcome } \\
\text { measures }\end{array}$ & Main results & AEs & $\begin{array}{c}\text { Author's conclusion } \\
\text { (quoted) }\end{array}$ \\
\hline $\begin{array}{l}\text { Oh } \\
(2010) \\
{[11]}\end{array}$ & $\begin{array}{l}\text { Cross- } \\
\text { over, DB }\end{array}$ & $\begin{array}{l}32 \text { Menopausal women } \\
\text { who had not menstru- } \\
\text { ated naturally for at } \\
\text { least } 1 \mathrm{yr}\end{array}$ & $40-60$ & KRG & 300 & 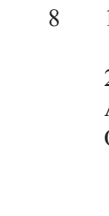 & $\begin{array}{l}\text { 1) Female Sexual } \\
\text { Function Index } \\
\text { 2) Global } \\
\text { Assessment } \\
\text { Questionnaire }\end{array}$ & $\begin{array}{l}\text { 11) Total: NS; desire: } \\
\text { NS; arousal: } \\
\mathrm{P}=0.006 \text {; lubrication: } \\
\text { NS; orgasm: NS; } \\
\text { satisfaction: NS; } \\
\text { pain: NS } \\
\text { 2) } \mathrm{P}=0.046\end{array}$ & $\begin{array}{l}12 \text { AEs } \\
\text { - Probable (vaginal bleeding, } \\
\text { KRG: } 2 \text {, once during KRG } \\
\text { period) } \\
\text { - No relation (10, not re- } \\
\text { ported in detail) }\end{array}$ & $\begin{array}{l}\text { '... an } 8 \text { wk in- } \\
\text { take of KRG is } \\
\text { associated with } \\
\text { improvement } \\
\text { of female } \\
\text { sexual function...' }\end{array}$ \\
\hline $\begin{array}{l}\text { Kim } \\
(2009) \\
{[12]}\end{array}$ & $\begin{array}{l}\text { Parallel, } \\
\text { DB }\end{array}$ & $\begin{array}{l}26 \text { Postmenopausal } \\
\text { women who had not } \\
\text { menstruated for at } \\
\text { least } 6 \text { months and had } \\
\text { severe hot flashes }\end{array}$ & $45-55$ & KRG & 900 & 8 & $\begin{array}{l}\text { Hot flashes } \\
\text { frequency }\end{array}$ & NS & None & $\begin{array}{l}\text { '...both RG } \\
\text { and placebo have } \\
\text { remarkable effects } \\
\text { on patients, but } \\
\text { RG is not better } \\
\text { than placebo' }\end{array}$ \\
\hline $\begin{array}{l}\text { Kim } \\
(2012) \\
{[13]}\end{array}$ & $\begin{array}{l}\text { Parallel, } \\
\text { DB }\end{array}$ & $\begin{array}{l}72 \text { Postmenopausal } \\
\text { women }\end{array}$ & $45-60$ & KRG & $\begin{array}{l}3,000 \\
\text { (including } \\
60 \mathrm{mg} \\
\text { ginsen- } \\
\text { osides }\end{array}$ & 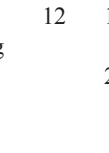 & $\begin{array}{l}\text { 1) Kupperman's } \\
\text { Index } \\
\text { 2) MRS }\end{array}$ & $\begin{array}{l}\text { 1) } \mathrm{P}=0.032 \text { in favour } \\
\text { of } \mathrm{KRG} \\
\text { 2) } \mathrm{P}=0.035 \text { in favour } \\
\text { of } \mathrm{KRG}\end{array}$ & Not assessed & $\begin{array}{l}\text { 'RG could be ... } \\
\text { relieving } \\
\text { menopausal } \\
\text { symptoms...' }\end{array}$ \\
\hline $\begin{array}{l}\text { Wiklund } \\
\text { (1999) } \\
{[14]}\end{array}$ & $\begin{array}{l}\text { Parallel, } \\
\text { DB }\end{array}$ & $\begin{array}{l}384 \text { Postmenopausal } \\
\text { women who had not } \\
\text { menstruated for at } \\
\text { least } 6 \text { months and had } \\
\text { hot flashes in at least } 3 \\
\text { of the previous } 7 \mathrm{~d}\end{array}$ & $45-65$ & $\begin{array}{l}\text { Ginseng } \\
\text { (Ginsana) }\end{array}$ & $\begin{array}{l}200 \\
\text { (effective } \\
\text { com- } \\
\text { pound: } \\
\text { G115) }\end{array}$ & 16 & $\begin{array}{l}\text { 1) Women's } \\
\text { Health } \\
\text { Questionnaire } \\
\text { 2) Psychological } \\
\text { General Well- } \\
\text { Being Index }\end{array}$ & $\begin{array}{l}\text { 1) NS } \\
\text { 2) Total: NS; anxiety: } \\
\text { NS; depression: } \\
\mathrm{P}=0.04 \text {; well-being: } \\
\mathrm{P}=0.05 \text {; Self-control: } \\
\mathrm{NS} \text {; health: } \mathrm{P}=0.03 \text {; } \\
\text { vitality: NS }\end{array}$ & $\begin{array}{l}181^{1)} \text { women reported but } \\
\text { no significant difference } \\
\text { between two groups } \\
\text { - Severe (G: } 7 ; \mathrm{C}: 9) \\
\text { - Probable (G: } 1 ; \mathrm{C}: 4) \\
\text { - Possible AE (G:7; C:10) } \\
\text { - Unknown (G:36; C:42) } \\
\text { - No relation (G:80; C: 77) } \\
\text { Influenza or cold (45); } \\
\text { headache and migraine (18); } \\
\text { diarrhoea and gastrointestinal } \\
\text { (40) }\end{array}$ & $\begin{array}{l}\text { '...ginseng extract } \\
\text { may offer effective } \\
\text { relief in QoL- } \\
\text { related aspects...' }\end{array}$ \\
\hline
\end{tabular}

DB, double blind; NS, not significant; P, probability; AE, adverse event; KRG, Korean red ginseng; MRS, menopausal rating scale; RG, red ginseng; G, ginseng; C, control; QoL, quality of life.

1) Original author reported 181 participants reported adverse events. However, this figure can be wrong because the sum of the number in ginseng group is 131 . 
cussed the results (MSK and HJL). Disagreements were resolved by discussion between the two reviewers with the opinion of the third reviewer (MSL) being sought if necessary. A meta-analysis had been considered but was deemed inappropriate due to the statistical and clinical heterogeneity of the primary studies.

\section{RESULTS}

A total of 87 articles were located, and 83 were excluded for the reasons given in Fig. 1. The remaining 4 RCTs were included, and their key data are summarized in Table 1 [11-14]. Three of the included studies were conducted in Korea, and one trial was from Sweden. Three trials used Korean red ginseng (KRG) [11-13], and the other employed ginseng (Ginsana) [14]. Three RCTs adopted a two-arms parallel group design [12-14], and one used a cross-over design [11].

\section{Risk of bias}

Two RCTs employed an adequate sequence generation method for randomization [11,13] (Table 2). The authors of one RCT reported that they used assessor blinding [11], while blinding of patients and practitioners was used in all of the RCTs. No RCT adopted an adequate method for allocation concealment. The risks of bias for reporting dropouts or withdrawals were low in three of the RCTs $[11,13,14]$. Two RCTs used an intention-to-treat analysis $[13,14]$. Two had a low risk of bias as to selective outcome reporting $[11,14]$.

\section{Outcomes}

One RCT showed that KRG improve in sexual arousal and global health compared with placebo [11]. A second RCT reported the superiority of KRG over placebo for treating menopause symptoms on Kupperman's index and Menopausal Rating Scale [13]. while the third failed to show a significant difference in hot flash frequency

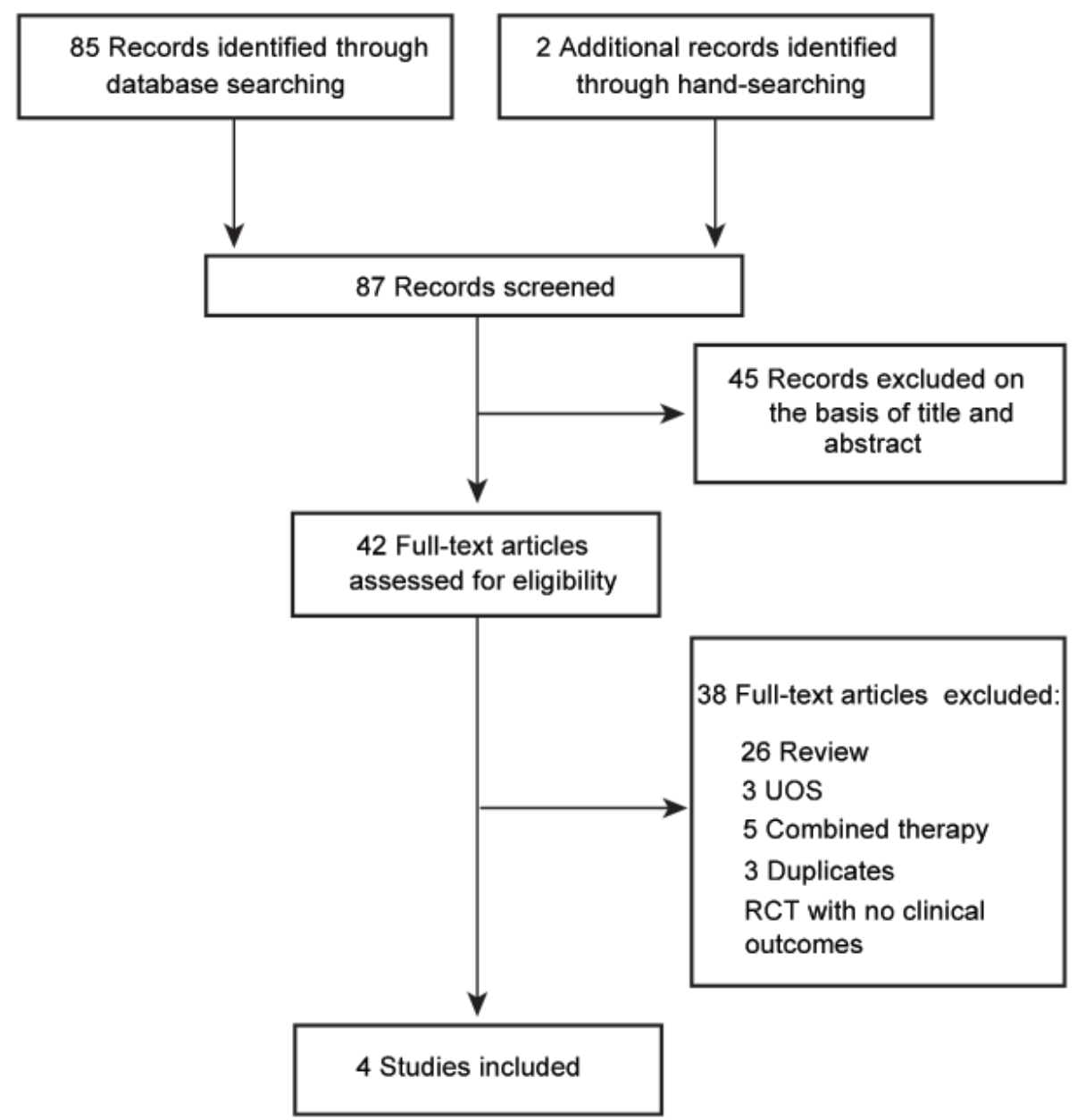

Fig. 1. Flowchart of trial selection process. UOS, uncontrolled observational study; RCT, randomized clinical trial. 
Table 2. Risk of bias in included trials

\begin{tabular}{|c|c|c|c|c|c|c|c|c|}
\hline First author (yr) [ref] & $\begin{array}{l}\text { Random } \\
\text { sequence } \\
\text { generation }\end{array}$ & $\begin{array}{c}\text { Allocation } \\
\text { concealment }\end{array}$ & $\begin{array}{c}\text { Patient and } \\
\text { practitioner } \\
\text { blinding }\end{array}$ & $\begin{array}{l}\text { Assessor } \\
\text { blinding }\end{array}$ & $\begin{array}{l}\text { Reporting } \\
\text { drop-out or } \\
\text { withdrawal }\end{array}$ & $\begin{array}{l}\text { Intention-to- } \\
\text { treat } \\
\text { analysis }\end{array}$ & $\begin{array}{l}\text { Selective } \\
\text { outcome } \\
\text { reporting }\end{array}$ & $\begin{array}{c}\text { Other } \\
\text { potential } \\
\text { bias }\end{array}$ \\
\hline Oh (2010) [11] & $\mathrm{L}$ & $\mathrm{U}$ & $\mathrm{L}$ & $\mathrm{L}$ & $\mathrm{L}$ & $\mathrm{H}$ & $\mathrm{L}$ & $\mathrm{U}$ \\
\hline $\operatorname{Kim}(2009)[12]$ & $\mathrm{U}$ & $\mathrm{U}$ & $\mathrm{L}$ & $\mathrm{U}$ & $\mathrm{U}$ & $\mathrm{U}$ & $\mathrm{U}$ & $\mathrm{H}$ \\
\hline $\operatorname{Kim}(2012)[13]$ & $\mathrm{L}$ & $\mathrm{U}$ & $\mathrm{L}$ & $\mathrm{U}$ & $\mathrm{L}$ & $\mathrm{L}$ & $\mathrm{U}$ & $\mathrm{U}$ \\
\hline Wiklund (1999) [14] & $\mathrm{U}$ & $\mathrm{U}$ & $\mathrm{L}$ & U & $\mathrm{L}$ & $\mathrm{L}$ & $\mathrm{L}$ & $\mathrm{U}$ \\
\hline
\end{tabular}

$\mathrm{L}$, low risk of bias; $\mathrm{U}$, unclear; $\mathrm{H}$, high risk of bias.

between the treatment and control groups [12]. One RCT compared a commercial ginseng preparation (Ginsana) on menopause symptoms with a placebo and found beneficial effects of ginseng on depression, well-being and general health [14].

\section{Adverse events}

Three of the RCTs reported adverse events (AEs) $[11,12,14]$. One RCT noted 12 AEs [11]. Two of the AEs were vaginal bleeding, which was most likely related to KRG use, but the other 10 AEs were unrelated to ginseng. The third noted that 181 out of 384 participants reported AEs [14]. The authors reported that 7 AEs were severe, 1 was probably, 7 were possibly, 36 were unknown and 80 were not related to treatments in ginseng group. The most frequent AEs included influenza or common cold (45), headache and migraine (18), and diarrhoea and other gastrointestinal symptoms (40). There was no significant difference in AEs between the treatment and control groups. One RCT did not assess the AEs [13].

\section{DISCUSSION}

Perhaps the most important finding of this systematic review is that there have been only a few rigorous trials of ginseng for treating menopausal symptoms. This systematic review identified only 4 RCTs of ginseng as a treatment of menopause symptoms. Three RCTs compared the effects of KRG with placebo [11-13], and the results were favourable for KRG on symptoms including sexual arousal, global health, and menopausal symptoms [11,13], while one RCT failed to do so in hot flush frequency [12]. One RCT found significant effects of ginseng supplements on well-being and depression compared with placebo [14]. The overall evidence of ginseng for managing menopausal symptoms is limited. However, the number of trials and total sample size were too low to draw firm conclusion.
All 4 RCTs were double blind, but all of the trials suffered from a lack of adequate allocation concealment. Trials with inadequate blinding and inadequate allocation concealment are likely to show exaggerated treatment effects [15]. Two of the included trials employed an intention-to-treat analysis $[13,14]$.

Although all of the RCTs used placebo controls, none reported the success of blinding or the degree of unblinding due to the distinct taste and smell of ginseng. Three RCTs used starch with ginseng flavour for placebo [1113], but the fourth did not report such details [14]. Unblinding would lead to an overestimation of the treatment effects, known as performance bias. Two RCTs failed to report details about ethical approval $[12,14]$.

One could argue that there are not currently enough RCTs to do a conclusive systematic review. However, it is not only a matter of the number of RCTs, but also one of methodological rigors, including features such as appropriate sample size, subject, practitioner or assessor blinding, and adequate allocation concealment. The main reason for conducting systematic review is to provide more reliable finding from which conclusion can be drawn and decisions made by using explicit, systematic methods [16].

The therapeutic effects of ginseng depend on the availability and amount of various constituents in the preparation. Yet the relevant details were sometimes missing. The optimum dose of red ginseng is unknown. Single dose studies used quantities of its extracts ranging from 300 to $3,000 \mathrm{mg}$. One of the trials used $300 \mathrm{mg}$ [11], while 1 used $900 \mathrm{mg}$ [12], 1 used 3,000mg [13], and 1 study used $200 \mathrm{mg}$ of active compound (G115) [14]. However, a clinical trial comparing dose dependency has not yet been published. Hence, the optimal dose and type of ginseng for menopausal symptoms cannot be recommended. Future trials of examining the types and dosage of ginseng can answer this question.

Possible mechanisms of action of ginseng on menopause symptoms include hormonal effects similar to 
those of oestrogen [9]. Ginsenosides, which are thought to be the principle active components of red ginseng, have been shown to exert oestrogen-like action without direct receptor binding [17,18]. More basic research is needed to fully understand the mechanisms of action of ginseng.

Reports of AEs with red ginseng were scarce, and those that were reported were mild. Vaginal bleeding was reported as an $\mathrm{AE}$ associated with red ginseng in 2 of the reviewed RCTs $[11,13]$. Another RCT showed that 131 participants reported AEs associated with ginseng [14]. Seven of these AEs were severe, 1 was probable and 7 were possible AEs. However, there was no significant difference in AEs between the treatment and control groups. Currently, no post-marketing surveillance studies for red ginseng or ginseng are available. A review of the safety profiles of red ginseng and ginseng reported no evidence of adverse drug reactions in humans with normal doses of red ginseng or ginseng but notes the lack of data on long-term use [19]. Adverse effects were not the focus of this review but the safety of ginseng is an important issue and needs to be addressed in future studies.

Our review has a number of important limitations. Although strong efforts were made to retrieve all RCTs on the subject, we cannot be certain that our searches located all relevant RCTs. Moreover, selective publishing and reporting are major sources of bias, which must be considered [20-22]. It is conceivable that several negative RCTs remain unpublished, and their absence could distort the overall picture. Further limitations include the paucity and the often suboptimal methodological quality of the primary data. Some of the RCTs included in the present review were not successful in minimizing bias. These issues limit the conclusiveness of this systematic review.

Future RCTs on ginseng for health care should adhere to accepted standards of trial methodology. The studies included in this review had a number of problems that have been noted by other reviews of trials examining the efficacy of ginseng e.g., types of ginseng, dosage, frequency and duration of treatment, the use of validated primary outcome measures and adequate statistical tests, and heterogeneous comparison groups. Furthermore, it is very important to use appropriate placebo treatment for blinding subjects to treatment, employing assessor blinding and allocation concealment are also important for reducing bias. Moreover, their reporting of clinical trials should follow CONSORT guideline [23].

In conclusion, the evidence on ginseng as an effective treatment for managing menopause symptoms is limited.
Most of the RCTs are burdened with a high risk of bias. Thus firm conclusions cannot be drawn. Rigorous studies seem warranted.

\section{ACKNOWLEDGEMENTS}

MS Kim and HJ Yang were supported by the research grant from the projects for the Globalization of Korean Foods (911010-02-1-SB010). MS Lee was supported by Korea Institute of Oriental Medicine (C12080 and K12340).

\section{REFERENCES}

1. Morris EP, Burbos N. Menopausal symptoms. Clin Evid (Online) 2010;2010:0804.

2. Ernst E, Pittler MH, Wider B, Boddy K. Oxford handbook of complementary medicine. Oxford: Oxford University Press, 2008.

3. Kass-Annese B. Alternative therapies for menopause. Clin Obstet Gynecol 2000;43:162-183.

4. Ernst E. Panax ginseng: an overview of the clinical evidence. J Ginseng Res 2010;34:259-263.

5. Kim SK, Park JH. Trends in ginseng research in 2010. J Ginseng Res 2011;35:389-398.

6. Park HJ, Kim DH, Park SJ, Kim JM, Ryu JH. Ginseng in traditional herbal prescriptions. J Ginseng Res 2012;36:225-241.

7. Jang DJ, Lee MS, Shin BC, Lee YC, Ernst E. Red ginseng for treating erectile dysfunction: a systematic review. Br J Clin Pharmacol 2008;66:444-450.

8. Seida JK, Durec T, Kuhle S. North American (Panax quinquefolius) and Asian ginseng (Panax ginseng) preparations for prevention of the common cold in healthy adults: a systematic review. Evid Based Complement Alternat Med 2011;2011:282151.

9. Shim M, Lee YJ. Ginseng as a complementary and alternative medicine for postmenopausal symptoms. J Ginseng Res 2009;33:89-92.

10. Higgins JP, Altman DG, Sterne JA. Assessing risk of bias in included studies. In: Higgins JP, Green S, eds. Cochrane handbook for systematic reviews of interventions. [Oxford]: Cochrane Collaboration, 2011. p.187-241.

11. Oh KJ, Chae MJ, Lee HS, Hong HD, Park K. Effects of Korean red ginseng on sexual arousal in menopausal women: placebo-controlled, double-blind crossover clinical study. J Sex Med 2010;7(4 Pt 1):1469-1477.

12. Kim HS, Yoon YJ, Lee JM, Lee CH, Jang JB, Lee KS, Cho JH. A clinical study on the effect of red ginseng for postmenopausal hot flushes. J Orient Obstet Gynecol 
2009;22:132-139.

13. Kim SY, Seo SK, Choi YM, Jeon YE, Lim KJ, Cho S, Choi YS, Lee BS. Effects of red ginseng supplementation on menopausal symptoms and cardiovascular risk factors in postmenopausal women: a double-blind randomized controlled trial. Menopause 2012;19:461-466.

14. Wiklund IK, Mattsson LA, Lindgren R, Limoni C. Effects of a standardized ginseng extract on quality of life and physiological parameters in symptomatic postmenopausal women: a double-blind, placebo-controlled trial. Swedish Alternative Medicine Group. Int J Clin Pharmacol Res 1999;19:89-99.

15. Schulz KF, Chalmers I, Hayes RJ, Altman DG. Empirical evidence of bias. Dimensions of methodological quality associated with estimates of treatment effects in controlled trials. JAMA 1995;273:408-412.

16. Green S, Higgins JP, Alderson P, Clarke M, Mulrow CD, Oxman AD. Introduction. In: Higgins JP, Green S, eds. Cochrane handbook for systematic reviews of interventions. [Oxford]: Cochrane Collaboration, 2011. p.3-9.

17. Amato P, Christophe S, Mellon PL. Estrogenic activity of herbs commonly used as remedies for menopausal symptoms. Menopause 2002;9:145-150.

18. Polan ML, Hochberg RB, Trant AS, Wuh HC. Estrogen bioassay of ginseng extract and ArginMax, a nutritional supplement for the enhancement of female sexual function. J Womens Health (Larchmt) 2004;13:427-430.

19. Coon JT, Ernst E. Panax ginseng: a systematic review of adverse effects and drug interactions. Drug Saf 2002;25:323-344.

20. Egger M, Smith GD. Bias in location and selection of studies. BMJ 1998;316:61-66.

21. Ernst E, Pittler MH. Alternative therapy bias. Nature 1997;385:480.

22. Rothstein H, Sutton AJ, Borenstein M. Publication bias in meta-analysis. In: Rothstein H, Sutton AJ, Borenstein M, eds. Publication bias in meta-analysis: prevention, assessment and adjustments. Chichester: Wiley, 2005. p.1-7.

23. Schulz KF, Altman DG, Moher D; CONSORT Group. CONSORT 2010 statement: updated guidelines for reporting parallel group randomised trials. BMJ 2010;340:c332. 
Appendix 1. MEDLINE search strategy

1. Menopause [MeSH]

2. Menopause, premature [MeSH]

3. Climacteric $[\mathrm{MeSH}]$

4. Premenopause $[\mathrm{MeSH}]$

5. Perimenopause $[\mathrm{MeSH}]$

6. Postmenopause [MeSH]

7. Vasomotor system $[\mathrm{MeSH}]$

8. Sweating [MeSH]

9. Hot flashes [MeSH]

10. Hot flush\$ [tw]

11. OR 1-10

12. Ginseng[MeSH]

13. (Panax ginseng or Panax quinquefolius)

14. (red ginseng or american ginseng).tw.

15. OR/12-14

16. randomized controlled trial [pt]

17. controlled clinical trial [pt]

18. placebo\$ [tw]

19. random $\$[\mathrm{tw}]$

20. single-blind method [MeSH]

21. double-blind method [MeSH]

22. prospective studies [MeSH]

23. controlled clinical trial [MeSH]

24. randomized controlled trial [MeSH]

25. clinical trials $[\mathrm{MeSH}]$

26. OR $16-25$

27. 11 AND 15 AND 26

28. Animals/not Humans/

29. 27 not 28 